\title{
PERSPECTIVE
}

\section{How much blue light should an IOL transmit?}

\author{
M A Mainster, J R Sparrow
}

Br J Ophthalmol 2003;87:1523-1529

Older, and even some modern, intraocular lenses (IOLs) transmit potentially hazardous ultraviolet radiation (UVR) to the retina. In addition, IOLs transmit more blue and green light to the retina for scotopic vision than the crystalline lenses they replace, light that is also potentially hazardous. The severity of UVR-blue type phototoxicity increases with decreasing wavelength, unlike the action spectrum of blue-green type retinal phototoxicity and the luminous efficiency of scotopic vision which both peak in the blue-green part of the optical spectrum around $500 \mathrm{~nm}$. Theoretically, UVR+blue absorbing IOLs provide better retinal protection but worse scotopic sensitivity than UVR-only absorbing IOLs, but further study is needed to test this analysis. UVR is potentially hazardous and not useful for vision, so it is prudent to protect the retina from it with chromophores in IOLs. Determining authoritatively how much blue light an optimal IOL should block requires definitive studies to determine (1) the action spectrum of the retinal phototoxicity potentially involved in human retinal ageing, and (2) the amount of shorter wavelength blue light required for older adults to perform essential activities in dimly lit environments.

See end of article for authors' affiliations .....................

Correspondence to: Martin A Mainster, PhD, MD, Department of Ophthalmology, MS3009, University of Kansas Medical Center, 3901 Rainbow Boulevard Kansas City, KS 661607379, USA; mmainste@ kumc.edu

Accepted for publication 1 September 2003
$\mathrm{T}$ he retina exists in a dangerous environment. Exposure to high concentrations of light and oxygen can damage photoreceptors and retinal pigment epithelial cells. ${ }^{1-3}$ Intraretinal defences decline as tissues age. ${ }^{3-9}$ Cells can self destruct when chemical triggers are activated..$^{10-15}$ Intraocular lenses (IOLs) increase light exposure of an ageing retina as its defences are declining. ${ }^{16-18}$ Ageing cannot be stopped but the optical radiation that IOLs transmit can be controlled.

Ultraviolet radiation (UVR) and visible light can cause photic retinopathy, also known as retinal photoxicity or foveomacular retinitis. ${ }^{19-23}$ Solar and operating microscope maculopathy are examples of acute retinal phototoxicity. The cornea and crystalline lens help protect the retina from photic retinopathy by preventing UVR from reaching the retina. The cornea blocks UVR with wavelengths below $300 \mathrm{~nm} .^{24-28}$ The crystalline lens blocks UVR between $300 \mathrm{~nm}$ and $400 \mathrm{~nm} \cdot{ }^{24-28}$ The ageing crystalline lens also blocks potentially phototoxic shorter wavelength blue light. ${ }^{24} 2629$

Cataract surgery increases the amount of optical radiation that reaches the retina. Intraocular lenses can compromise ocular defences against photic retinopathy, a problem first reported in
1978. ${ }^{16}{ }^{17}$ IOLs with UVR blocking chromophores bonded to optic polymers (UVR-only absorbing IOLs) were introduced in the early 1980s, but even some modern IOLs have inadequate UVR protection. ${ }^{18}{ }^{3031}$ IOLs that absorb blue as well as UVR radiation (UVR+blue absorbing IOLs) were introduced in the 1990s. ${ }^{32}$

UVR is not useful for human vision, so it makes good sense to use IOL chromophores to prevent it from reaching the retina. How much blue light to block is a more difficult decision, however, because the action spectrum of retinal phototoxicity potentially involved in macular ageing is currently unknown, scotopic vision decreases faster than photopic vision in older adults, and blue light is more important in scotopic than photopic vision. ${ }^{33-39}$ In essence, light transmission through an IOL is a trade off between visual performance and protection against retinal phototoxicity. That balance can be quantified theoretically using standard data on scotopic visual sensitivity ${ }^{40}$ and retinal phototoxicity. ${ }^{41-44}$

\section{SCOTOPIC VISION AND AGEING}

Photopic sensitivity for an eye adapted to bright luminances peaks at $555 \mathrm{~nm}$ in the green-yellow part of the spectrum. ${ }^{40}$ Scotopic sensitivity for an eye adapted to dim luminances peaks at $506 \mathrm{~nm}$ in the blue-green part of the spectrum. ${ }^{40}$ The Commission Internationale de l'Eclairage (CIE) standard spectral luminous efficiency functions for photopic and scotopic vision are $V_{\lambda}$ and $V^{\prime}{ }_{\lambda}$, respectively. ${ }^{40}$ They are illustrated in Figure 1, which shows that scotopic vision is much more dependent on blue light than photopic vision. The similarity between scotopic luminosity $\mathrm{V}_{\lambda}$ and the absorption spectrum for rhodopsin in human rod photoreceptors (which peaks at $498 \mathrm{~nm})^{45}$ was a key reason for concluding that rhodopsin mediates scotopic vision. ${ }^{46}$ Similarly, the resemblance between the absorption spectrum of rhodopsin and the action spectrum of blue-green type retinal photoxicity suggests that rhodopsin may have an important role in this type of photic retinopathy. ${ }^{6} 194748$

Visual performance decreases with ageing on most sensory tests, even in individuals with normal high contrast visual acuity. ${ }^{49-53}$ Ageing has little effect on the number of human foveal cone photoreceptors, but parafoveal rod photoreceptors decrease by $30 \%$ with increasing age. $^{3854}$ The mechanisms of this loss remain under investigation, but it probably has a significant role in the declining scotopic vision of older adults. ${ }^{55}$ Scotopic visual sensitivity decreases twice as fast as photopic sensitivity with increasing age, a loss that contributes to older adults' visual difficulties in dim 


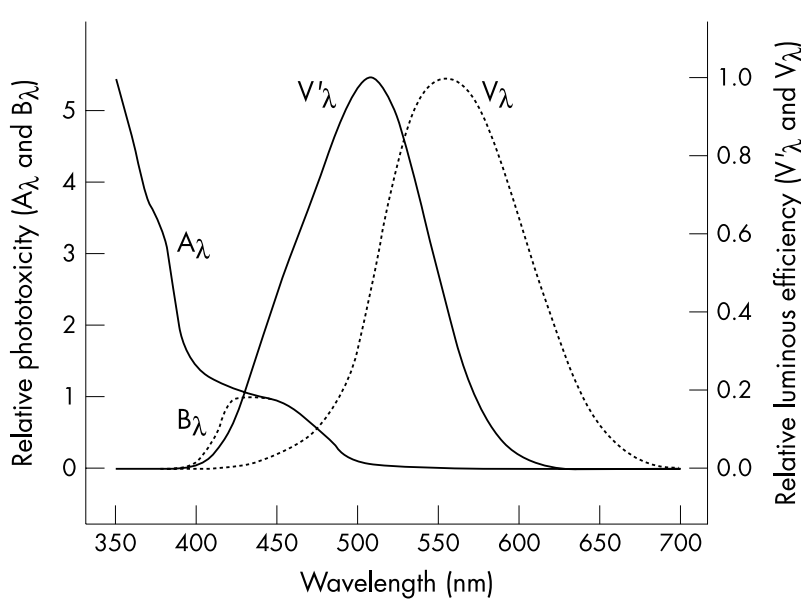

Figure $1 \quad A_{\lambda}$ and $B_{\lambda}$ describe how UVR-blue type phototoxicity varies with wavelength in an aphakic and a phakic eye, respectively. ${ }^{41-43} \mathrm{~V}^{\prime}{ }_{\lambda}$ and $V_{\lambda}$ are the relative spectral luminous scotopic and photopic efficiencies, respectively, of the standard CIE observer. ${ }^{40}$ They characterise how scotopic and photopic visual sensitivity vary with wavelength in a normal phakic eye. ${ }^{40} 170$

environments and that occurs independent of retinal disease or ocular optical problems. ${ }^{34} 36{ }^{38}$ Rod mediated dark adaptation slows progressively with ageing because of delayed rhodopsin regeneration. ${ }^{34}$ Scotopic contrast sensitivity at low and high spatial frequencies declines with increasing age. ${ }^{35}$ Ageing related loss of scotopic sensitivity is worst in the blue part of the spectrum. ${ }^{57}$ Macular degeneration worsens age related decreases in scotopic vision. ${ }^{37} 385859$

Visual difficulties can limit the activities and reduce the quality of life of older adults. ${ }^{5260-64}$ Fear of events such as a hip fracture from a fall can prompt older individuals to limit their activities. ${ }^{63}$ Impaired dark adaptation is associated with an increased risk of falling. ${ }^{65}$ Older individuals need to be closer to road signs to read them effectively at night. ${ }^{66}$ Vision problems may prompt older drivers to curtail their night-time driving activities. ${ }^{39} 52$ 67-69 In general, visual problems in dim environments increase with ageing, and improved scotopic vision is an appropriate goal for cataract surgery and IOL design. The bottom line is that older adults have increasing problems seeing at night or in dim environments even when they don't have crystalline lens or retinal problems. ${ }^{49-53}$

\section{PHOTIC RETINOPATHY AND AGEING}

Photic retinopathy has been studied as an ocular hazard and used as a technique to investigate retinal degeneration and cell biology. The oxygen rich environment of the neural retina and retinal pigment epithelium (RPE) increases their vulnerability to light damage..$^{40-74}$ Ocular media are the first line of defence against photic retinopathy, but the retina has its own internal defences against phototoxicity, including agents such as superoxide dismutase, catalase, glutathione peroxidase, vitamin E, vitamin C, lutein, and zeaxanthin. ${ }^{6}{ }^{71} 75-77$

Photic retinopathy has been studied extensively since it was first reported in $1966 .{ }^{19}$ It occurs at chorioretinal temperature elevations far too low for retinal photocoagulation. ${ }^{78-80}$ Retinal photocoagulation is thermal damage caused by radiant heating of the retina and choroid, whereas photic retinopathy is actinic damage caused by photochemical reactions in the neural retina and/or RPE.

Phototoxicity is accelerated by higher body temperature $^{197881}$ and elevated blood oxygen concentration. ${ }^{12}$ Genetic factors, ${ }^{82-84}$ time of day, ${ }^{85-88}$ and $\operatorname{diet}^{89-92}$ all affect the susceptibility of experimental animals to photic retinopathy. Different mechanisms cause phototoxicity in the neural retina and RPE, selective damage at each of these sites being dependent on exposure protocols and animal species. ${ }^{4893}$ There is reciprocity between retinal irradiance (power/area) and exposure time, so longer exposures produce threshold phototoxicity at lower irradiances. ${ }^{48}$ Retinal phototoxicity is probably additive so that previous exposure increases the risk of subsequent damage. ${ }^{95}$

Retinal defences against photic retinopathy decline with ageing. ${ }^{3-9}$ Environmental light exposure has been postulated to be a potential causative factor in macular degeneration for almost a century, ${ }^{6} 17237796-100$ and there are striking similarities in the retinal abnormalities caused by age related macular degeneration and repetitive acute phototoxicity. ${ }^{1797101102}$ Unfortunately, epidemiological studies correlating macular degeneration with light exposure are problematical because individual susceptibility varies and lifelong photic exposure is difficult to determine accurately in retrospective studies. Some studies have shown a correlation between macular degeneration and lifelong light exposure, whereas others have not found them to be correlated. ${ }^{103-110}$ Additionally, studies correlating cataract surgery with postoperative progression of macular degeneration also have produced conflicting results. ${ }^{111-119}$

An action spectrum characterises the relative effectiveness of different wavelengths in producing a photochemical effect. There are at least two classes of action spectra for retinal phototoxicity.

For lengthy exposures typically shorter than 12 hours in aphakic animals, retinal phototoxicity has an action spectrum that increases with decreasing wavelength, as shown by $\mathrm{A}_{\lambda}$ (for aphakic) in Figure $1^{20}{ }^{41-43} 47488^{120-123}$ This UVR-blue type of retinal photoxicity has been termed blue light, class 2 or Ham type photic retinopathy. It has also been termed "blue light" damage because its action spectrum peaks around $440 \mathrm{~nm}$ when a crystalline lens blocks UVR and shorter wavelength blue light, as shown by $\mathrm{B}_{\lambda}$ (for $b$ lue) in Figure $1 .{ }^{41-43}$

For prolonged exposures typically longer that 12 hours, phototoxicity has an action spectrum that peaks in the bluegreen part of the spectrum, similar to the absorption spectrum of rhodopsin or that of scotopic luminous efficiency $\left(\mathrm{V}_{\lambda}^{\prime}\right.$ in Fig 1). ${ }^{19} 41-434748121124$ This blue-green type of retinal phototoxicity has been referred to as white light, class 1 , or Noell type photic retinopathy. Blue-green type retinal phototoxicity occurs at substantially lower retinal irradiances than UVR-blue type retinal phototoxicity, but very prolonged exposures are required to produce damage in a single irradiation. ${ }^{47} 48121$

The photosensitisers responsible for photic retinopathy have not been determined conclusively. Rhodopsin, its photoproducts, or cytochrome-c oxidase in mitochondria may be involved. ${ }^{19}{ }^{21}{ }^{93}$ 125-128 A growing body of evidence suggests that lipofuscin fluorophores-for instance, the pyridinium bisretinoid A2E, ${ }^{129}$ may play significant parts in RPE phototoxicity and macular ageing, ${ }^{15} 73^{130-137}$ and that the photoxidative products of $\mathrm{A} 2 \mathrm{E}$ are the agents that damage cellular molecules..$^{136} 138139$

$\mathrm{A} 2 \mathrm{E}$ has an excitation maximum of approximately $430 \mathrm{~nm},{ }^{133}{ }^{140}$ a property that may contribute to the susceptibility of RPE to blue light damage in vivo. ${ }^{20}{ }^{141}$ Most of the lipofuscin that is amassed by RPE originates from conjugates generated by visual cycle retinoids in photoreceptor cells, ${ }^{138}{ }^{142-144}$ this material being deposited in RPE cells subsequent to outer segment disc phagocytosis. ${ }^{145}$ These retinoid conjugates accumulate because they are not broken down enzymatically. Accordingly, lipofuscin levels in the RPE increase with age, ${ }^{146-148}$ and the highest levels are present in macular RPE. ${ }^{148-151}$ The role of RPE melanin as a 
photosensitiser and/or photoprotective agent in photic retinopathy remains under investigation, ${ }^{135}{ }^{152-154}$ but the presence of melanin is not essential for RPE phototoxicity. ${ }^{133}$

\section{IOL PROTECTION AND PERFORMANCE}

IOLs were initially fabricated from poly(methylmethacrylate) (PMMA) without UVR blocking chromophores. ${ }^{16}$ The dangers of retinal exposure to near-UVR transmitted by clear PMMA IOLs were recognised in $1978^{16}{ }^{17}$ and most IOLs had UVR absorbing chromophores by $1986 .{ }^{18}$ Unfortunately, UVR protection in contemporary IOLs is inconsistent, and some manufacturers still produce IOLs that transmit potentially phototoxic near-UVR to the retina. ${ }^{31}$

The advantages of UVR-only absorbing IOLs are well documented. UVR-only protective IOLs transmit more blue light than a crystalline lens, ${ }^{155}$ but they decrease the incidence of erythropsia ${ }^{156-159}$ and blue cone sensitivity loss in pseudophakes. ${ }^{160}$ They also decrease blood-retinal barrier disruption in pseudophakes as measured by vitreous fluorophotometry $^{161}$ and the risk of retinal phototoxicity in experimental animals. ${ }^{162}{ }^{163}$ UVR+blue absorbing IOLs increase photopic and mesopic contrast sensitivity at intermediate spatial frequencies. ${ }^{32}$ UVR-only protective IOLs were reported initially to decrease the risk of angiographically apparent cystoid macular oedema (CMO), ${ }^{164}$ but a later study found no such effect in individuals with a ultraviolet protective lens in one eye and a non-ultraviolet-absorbing lens in their other eye. ${ }^{165}$

Blocking UVR with IOL chromophores increases protection from photic retinopathy without decreasing visual sensitivity. It also seemed appropriate in 1986 to use IOL chromophores to decrease the amount of shorter wavelength blue light reaching the retina. ${ }^{18}$ Now that a growing body of scientific evidence has demonstrated that ageing related decreases in scotopic sensitivity cannot be attributed solely to optical changes but may involve rod and ganglion cell loss as well as central visual pathway alterations, ${ }^{34-36} 38166$ how much shorter wavelength blue light should be attenuated by IOL chromophores to reduce the potential risk of retinal phototoxicity?

The scotopic luminous efficiency $\left(\mathrm{V}_{\lambda}^{\prime}\right)$ and aphakic phototoxicity $\left(\mathrm{A}_{\lambda}\right)$ standards shown in Figure 1 can be used to examine how the optical transmittance spectrum of a crystalline or intraocular lens affects scotopic vision and the risk of photic retinopathy. The areas under the $\mathrm{V}_{\lambda}^{\prime}$ and $\mathrm{A}_{\lambda}$ curves in Figure 1 represent total scotopic sensitivity and total aphakic UVR-blue retinal phototoxicity, respectively. If $\mathrm{V}_{\lambda}^{\prime}$ and $A_{\lambda}$ are convolved with a transmittance spectrum of a particular lens, the percentage difference between the original and convolved areas under the curve represents the percentage loss in scotopic sensitivity or gain in UVR-blue phototoxicity protection from the lens.

Calculations were performed for the five lenses shown in Figure 2, which included two UVR-only absorbing IOLs, one UVR+blue absorbing IOL, and a 53 year old and 75 year old crystalline lens. The results of this analysis are presented in Table 1. As expected, the calculations predict that increasing retinal protection with an IOL decreases its overall scotopic performance and that the UVR+blue absorbing IOL affords better retinal protection but worse scotopic performance than the conventional UVR-only absorbing IOLs. Only clinical studies can determine the potential significance of these theoretical predictions.

The results in Table 1 are subject to numerous limitations: (1) If chronic environmental light exposure does play an important part in macular ageing, it probably affects individuals quite differently depending on unrelated environmental factors such as smoking and on pigmentation and other genetic factors such as the rate at which A2E accumulates in RPE cells, which in turn may be affected by

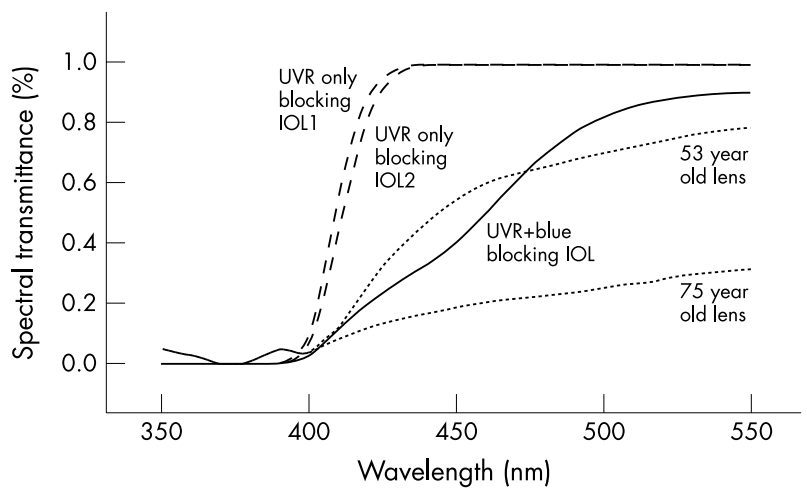

Figure 2 The percentage spectral transmittance of crystalline and intraocular lenses listed in Table 1. Spectral transmittance data on 20D UVR-only absorbing IOL 1 (Alcon AcrySof MA6OBM) and 2 (Pharmacia \& Upjohn 720A) 20D lenses are from Lin, et al. ${ }^{31}$ UVR+blue absorbing IOL data (Alcon AcrySof Natural 20D lens) are from Mr Raphael Chan, Alcon Surgical Division, Forth Worth, TX, USA. The 53 and 75 year old crystalline lens transmittance data are from Boettner and Wolter. ${ }^{24}$

Table 1 Theoretical predictions of how several IOLs and human crystalline lenses decrease scotopic visual sensitivity and increase protection from blue-green type photic retinopathy

\begin{tabular}{|c|c|c|}
\hline Lens & $\begin{array}{l}\% \text { decrease in } \\
\text { scotopic visual } \\
\text { sensitivity }\end{array}$ & $\begin{array}{l}\% \text { increase in } \\
\text { protection from } \\
\text { UVR blue type } \\
\text { phototoxicity† }\end{array}$ \\
\hline 75 year old crystalline lensł & 75 & 93 \\
\hline 53 year old crystalline lens & 33 & 86 \\
\hline UVR+blue absorbing IOL§ & 27 & 90 \\
\hline UVR-only blocking IOL, No 1 - & 1.5 & 75 \\
\hline UVR-only blocking IOL, No $2^{* *}$ & 1.6 & 76 \\
\hline
\end{tabular}

*The percentage difference between the total areas under the $\mathrm{V}_{\lambda}{ }_{\lambda}$ curve in Figure 1 and that curve convolved with the spectral transmittance of a particular lens.

TThe percentage difference between the total areas under the $A_{\lambda}$ curve in Figure 1 and that curve convolved with the spectral transmittance of a particular lens.

‡Data on human crystalline lens transmittance are from Boettner and Wolter. ${ }^{24}$

\$Alcon acrylic AcrySof Natural 20D lens. IOL transmittance data are from Mr Rafael Chan, Alcon Surgical Division, Forth Worth, TX, USA. -Alcon acrylic AcrySof MA60BM 20D lens. IOL transmittance data are from Lin et al. ${ }^{31}$

**Pharmacia \& Upjohn poly(methylmethacrylate) 720A 20D lens. IOL transmittance data are from Lin et al. ${ }^{31}$

abcr gene mutations. ${ }^{167}$ (2) $\mathrm{V}_{\lambda}^{\prime}$ does describe overall scotopic performance, but it represents the performance of a phakic "standard CIE observer"40 168 rather than an aphakic older adult. Psychophysical studies are needed to determine: (a) how much shorter wavelength blue light is needed for older adults to perform essential scotopic tasks in dimly illuminated environments, and (b) whether the shorter wavelength blue light attenuated by a UVR+blue absorbing IOL but transmitted by a UVR-only absorbing IOL can compensate in any significant way for ageing related losses in scotopic sensitivity. (3) $A_{\lambda}$ does characterise threshold, acute, UVRblue type photic retinopathy in experimental animals, but it may differ significantly from the action spectrum of the repetitive or chronic retinal phototoxicity potentially involved in but not conclusively proved to have a significant role in human retinal ageing. (4) Recent threshold studies on primate retinal phototoxicity have found that some of the classic data incorporated into the international $\mathrm{A}_{\lambda}$ standard 
may significantly overestimate the UVR-blue type phototoxicity of shorter wavelength blue light. ${ }^{169}$ Thus, international phototoxicity standards may change, and results in Table 1 based on $A_{\lambda}$ probably significantly overestimate the protection from phototoxicity provided by UVR-only and UVR+blue absorbing IOLs.

\section{DISCUSSION}

Cataract surgery removes the crystalline lens which provides optical protection against retinal phototoxicity in an ageing eye. Light absorbing chromophores in an IOL determine which optical wavelengths are transmitted to the retina, balancing retinal protection with visual performance.

An ideal IOL would adapt to changing illumination, transmitting all visible light in dim environments for optimal scotopic performance, but blocking a variable amount of visible light in bright environments depending on an individual's visual requirements and chorioretinal condition. Adaptive photochromic IOLs are not available. The two current choices are UVR-only and UVR+blue absorbing IOLs. In both cases, sunglasses and other forms of ocular protection such as a brimmed hat probably should be worn in very bright environments because of the potential risk of bluegreen type retinal phototoxicity.

As shown in Table 1, UVR only blocking IOLs theoretically provide less protection from UVR-blue type phototoxicity than UVR+blue absorbing IOLs. If only the spectral region between $400-550 \mathrm{~nm}$ is considered, this protection is roughly a third of that of UVR+blue absorbing IOLs. Conversely, UVRonly blocking IOLs theoretically do not significantly diminish scotopic visual sensitivity. These data predict that UVR+blue absorbing IOLs diminish scotopic visual sensitivity by roughly $25 \%$, but the practical significance of that loss is unknown. The preceding analysis addresses only UVR-blue type retinal phototoxicity, not the blue-green type retinal phototoxicity which has an action spectrum similar to the spectral sensitivity of scotopic vision or the absorption spectrum of rhodopsin. Any increase in protection against blue-green type phototoxicity that an IOL provided would be accompanied by an equivalent percentage decrease in scotopic sensitivity.

One might argue that replacing an ageing crystalline lens with a UVR-only blocking IOL increases the amount of potentially hazardous blue light reaching senescent macular RPE with its increased lipofuscin content, that decreasing blue light even in non-brilliant photopic environments could decrease background UVR-blue type phototoxic damage which might have a role in macular ageing, that shorter wavelength blue light has not been proved to be valuable for essential scotopic visual tasks of older adults after IOL implantation, and that blue light absorbing chromophores in an IOL are always there for some optical radiation protection even in individuals who fail to wear sunglasses in appropriate circumstances.

Conversely, one might argue that UVR-blue type of phototoxicity has not been proved to have a significant role in human macular ageing, that improved blue light transmission might help compensate for visual losses as a result of decreased rod photoreceptor density in ageing, that the hypothetical benefit of avoiding fractures from tripping in dim illumination is more significant than the hypothetical benefit of decreasing the risk of age related macular degeneration, and that it's easier to switch sunglasses than IOLs should future research demonstrate that shorter wavelength blue light is useful for the scotopic vision of older adults.

Neither author has an IOL, but if and when we need one, we would both make sure that it had appropriate UVR blocking chromophores. Based on current information, one of us (MAM) would choose to have a UVR-only blocking IOL that would provide maximal protection against UVR, and wear sunglasses in very bright environments, which could be removed for optimal vision in dim environments. JRS would choose a UVR+blue absorbing IOL that would provide maximal protection against UVR, afford roughly the same protection against phototoxicity and diminution of scotopic sensitivity as a 50 year old crystalline lens, and wear sunglasses in very bright environments, which could be removed for improved vision in dimmer environments. Until photochromic IOLs become available, the decision on which strategy is optimal awaits conclusive data on the role of UVRblue type retinal phototoxicity in age related macular degeneration and the value of shorter wavelength blue light in essential scotopic activities of older adults.

\section{Authors' affiliations}

M A Mainster, Department of Ophthalmology, University of Kansas Medical School, Kansas City, KS, USA

J R Sparrow, Department of Ophthalmology, Columbia University, New York, NY, USA

Supported in part by the Kansas Lions Sight Foundation, Inc (MAM), grant EY-12951 from the National Eye Institute, Bethesda MD (JRS), and a grant from Alcon (JRS).

The authors have no proprietary interests in the development or marketing of any product mentioned in this study.

\section{REFERENCES}

1 Ruffolo JJ Jr, Ham WT Jr, Mueller HA, et al. Photochemical lesions in the primate retina under conditions of elevated blood oxygen. Invest Ophthalmol Vis Sci 1984;25:893-8.

2 Crockett RS, Lawwill T. Oxygen dependence of damage by $435 \mathrm{~nm}$ light in cultured retinal epithelium. Curr Eye Res 1984;3:209-15.

3 Beatty S, Koh H, Phil M, et al. The role of oxidative stress in the pathogenesis of age-related macular degeneration. Surv Ophthalmol 2000;45:115-34.

4 Robison WG, Kuwabara T, Bieri JG. The roles of vitamin E and unsaturated fatty acids in the visual process. Retina 1982;2:263-81.

5 Marshall J. The ageing retina: physiology or pathology. Eye 1987; 1 (Pt 2):282-95.

6 Mainster MA. Light and macular degeneration: a biophysical and clinical perspective. Eye 1987;1(Pt 2):304-10.

7 Hunyor $A B$. Solar retinopathy: its significance for the ageing eye and the younger pseudophakic patient. Aust N Z J Ophthalmol 1987;15:371-5.

8 Roberts JE. Ocular phototoxicity. J Photochem Photobiol B 2001;64:136-43.

9 Bernstein PS, Zhao DY, Wintch SW, et al. Resonance Raman measurement of macular carotenoids in normal subjects and in age-related macular degeneration patients. Ophthalmology 2002;109:1780-7.

10 Abler AS, Chang CJ, Ful J, et al. Photic injury triggers apoptosis of photoreceptor cells. Res Commun Mol Pathol Pharmacol 1996;92:177-89.

11 Wu J, Seregard S, Spangberg B, et al. Blue light induced apoptosis in rat retina. Eye 1999;13(Pt 4):577-83.

12 Wenzel A, Grimm C, Marti A, et al. c-fos controls the "private pathway" of light-induced apoptosis of retinal photoreceptors. J Neurosci 2000;20:81-8.

13 Thanos S, Heiduschka P, Romann I. Exposure to a solar eclipse causes neuronal death in the retina. Graefes Arch Clin Exp Ophthalmol $2001 ; 239: 794-800$

14 Dunaief JL, Dentchev T, Ying GS, et al. The role of apoptosis in age-related macular degeneration. Arch Ophthalmol 2002;120:1435-42.

15 Sparrow JR, Zhou J, Ben-Shabat S, et al. Involvement of oxidative mechanisms in blue-light-induced damage to A2E-laden RPE. Invest Ophthalmol Vis Sci 2002;43:1222-7.

16 Mainster MA. Spectral transmittance of intraocular lenses and retinal damage from intense light sources. Am J Ophthalmol 1978;85:167-70.

17 Mainster MA. Solar retinitis, photic maculopathy and the pseudophakic eye. J Am Intraocul Implant Soc 1978;4:84-6.

18 Mainster MA. The spectra, classification, and rationale of ultravioletprotective intraocular lenses. Am J Ophthalmol 1986;102:727-32.

19 Noell WK, Walker VS, Kang BS, et al. Retinal damage by light in rats. Invest Ophthalmol 1966;5:450-73.

20 Ham WT Jr, Mueller HA, Sliney DH. Retinal sensitivity to damage from short wavelength light. Nature 1976;260:153-5.

21 Lawwill T. Three major pathologic processes caused by light in the primate retina: a search for mechanisms. Trans Am Ophthalmol Soc 1982;80:517-79.

22 Mainster MA, Ham WT Jr, Delori FC. Potential retinal hazards. Instrument and environmental light sources. Ophthalmology 1983;90:927-32.

23 Mainster MA, Turner PL. Photic retinal injury and safety. In: Ryan SJ, Ogden TE, Hinton DR, Schachat AP, eds. Retina. 3rd ed. St Louis: Mosby, 2001:1797-809.

24 Boettner EA, Wolter JR. Transmission of the ocular media. Invest Ophthalmol 1962;1:776-83. 
25 Van Norren D, Vos JJ. Spectral transmission of the human ocular media. Vis Res 1974;14:1237-44.

26 Mellerio J. Yellowing of the human lens: nuclear and cortical contributions. Vis Res 1987;27:1581-7.

27 Weale RA. Age and the transmittance of the human crystalline lens. J Physiol 1988;395:577-87

28 Griswold MS, Stark WS. Scotopic spectral sensitivity of phakic and aphakic observers extending into the near ultraviolet. Vis Res 1992;32:1739-43.

29 Bron AJ, Vrensen GF, Koretz J, et al. The ageing lens. Ophthalmologica 2000;214:86-104.

30 Lindstrom RL, Doddi N. Ultraviolet light absorption in intraocular lenses. J Cataract Refract Surg 1986;12:285-9.

31 Lin K, Lin Y, Lee J, et al. Spectral transmission characteristics of spectacle, contact, and intraocular lenses. Ann Ophthalmol 2002;34:206-15.

32 Niwa K, Yoshino Y, Okuyama F, et al. Effects of tinted intraocular lens on contrast sensitivity. Ophthalmic Physiol Opt 1996;16:297-302.

33 Jackson GR, Owsley C, Cordle EP, et al. Aging and scotopic sensitivity. Vis Res 1998;38:3655-62.

34 Jackson GR, Owsley C, McGwin G Jr. Aging and dark adaptation. Vis Res 1999;39:3975-82.

35 Schefrin BE, Tregear SJ, Harvey LO Jr, et al. Senescent changes in scotopic contrast sensitivity. Vis Res 1999;39:3728-36.

36 Jackson GR, Owsley C. Scotopic sensitivity during adulthood. Vis Res 2000;40:2467-73.

37 Owsley C, Jackson GR, White $M$, et al. Delays in rod-mediated dark adaptation in early age-related maculopathy. Ophthalmology 2001;108:1196-202.

38 Jackson GR, Owsley C, Curcio CA. Photoreceptor degeneration and dysfunction in aging and age-related maculopathy. Ageing Res Rev 2002;1:381-96.

39 Mainster MA, Timberlake G. Why HID headlights bother older drivers. Br J Ophthalmol 2003;87:113-17.

40 Wyszecki G, Stiles WS. Color science. New York: John Wiley \& Sons, 1967.

41 American Conference of Governmental Industrial Hygienists. Threshold limit values for chemical substances physical agents: biological exposure indices. Cincinnati: ACGIH, 1997.

42 International Commission on Non-lonizing Radiation Protection. Guidelines on limits of exposure to broad-band incoherent optical radiation $(0.38$ to 3 microM). Health Phys 1997;73:539-54.

43 Sliney DH, Bitran M. The ACGIH action spectra for hazard assessment: The TLV's. In: Matthes R, Sliney DH, ed. Measurements of optical radiation hazards. Oberschleissheim, Germany: International Commission on Nonlonizing Radiation Protection (ICNIRP 6/98) and CIE (x0161998), 1998:241-29.

44 American Conference of Governmental Industrial Hygienists. Threshold limit values and biological exposure indices. Cincinnati: ACGIH, 2000.

45 Crescitelli F, Dartnall HJA. Human visual purple. Nature 1953; 172: 195-200

46 Hsia Y. Photochemistry of vision. In: Graham CH, Bartlett NR, Brown JL, Hsia Y, Mueller CG, Riggs LA, eds. Vision and visual perception. New York: John Wiley and Sons, 1966.

47 Kremers JJ, van Norren D. Two classes of photochemical damage of the retina. Lasers Light Ophthalmol 1988;2:41-52.

48 Mellerio J. Light effects on the retina. In: Albert DM, Jakobiec FA, eds. Principles and practice of ophthalmology. Philadelphia: WB Saunders, 1994:1326-45.

49 Haegerstrom-Portnoy G, Schneck ME, Brabyn JA. Seeing into old age: vision function beyond acuity. Optom Vis Sci 1999;76:141-58

50 Ivers RQ, Mitchell P, Cumming RG. Visual function tests, eye disease and symptoms of visual disability: a population-based assessment. Clin Exp Ophthalmol 2000;28:41-7

51 Rubin GS, West SK, Munoz B, et al. A comprehensive assessment of visual impairment in a population of older Americans. The SEE Study. Salisbury Eye Evaluation Project. Invest Ophthalmol Vis Sci 1997-38:557-68.

52 Klein BE, Klein R, Lee KE, et al. Associations of performance-based and selfreported measures of visual function. The Beaver Dam Eye Study. Ophthalmic Epidemiol 1999;6:49-60.

53 Johnson CA, Keltner JL. Incidence of visual field loss in 20,000 eyes and its relationship to driving performance. Arch Ophthalmol 1983;101:371-5.

54 Curcio CA, Millican CL, Allen KA, et al. Aging of the human photoreceptor mosaic: evidence for selective vulnerability of rods in central retina. Invest Ophthalmol Vis Sci 1993:34:3278-96.

55 Curcio CA, Owsley C, Jackson GR. Spare the rods, save the cones in aging and age-related maculopathy. Invest Ophthalmol Vis Sci 2000;41:2015-8.

56 Curcio CA. Photoreceptor topography in ageing and age-related maculopathy. Eye 2001;15(Pt 3):376-83.

57 Gunkel RD, Gouras P. Changes in scotopic visibility thresholds with age. Arch Ophthalmol 1963;69:38-43

58 Sunness JS, Rubin GS, Applegate CA, et al. Visual function abnormalities and prognosis in eyes with age-related geographic atrophy of the macula and good visual acuity. Ophthalmology 1997;104:1677-91.

59 Owsley C, Jackson GR, Cideciyan AV, et al. Psychophysical evidence for rod vulnerability in age-related macular degeneration. Invest Ophthalmol Vis Sci 2000;41:267-73.

60 Kosnik W. Winslow L, Kline D, et al. Visual changes in daily life throughout adulthood. J Gerontol 1988;43:63-70.

61 Mangione CM, Berry S, Spritzer K, et al. Identifying the content area for the 51-item National Eye Institute Visual Function Questionnaire: results from focus groups with visually impaired persons. Arch Ophthalmol $1998 ; 116: 227-33$
62 Brown GC. Vision and quality-of-life. Trans Am Ophthalmol Soc 1999:97:473-511.

63 Klein BE, Moss SE, Klein R, et al. Associations of visual function with physical outcomes and limitations 5 years later in an older population: the Beaver Dam eye study. Ophthalmology 2003:1 10:644-50.

64 Brown MM, Brown GC, Sharma S, et al. Quality of life associated with visual loss: a time tradeoff utility analysis comparison with medical health states. Ophthalmology 2003;110:1076-81.

65 McMurdo ME, Gaskell A. Dark adaptation and falls in the elderly. Gerontology 1991;37:221-4

66 Sivak M, Olson PL, Pastalan LA. Effect of driver's age on nighttime legibility of highway signs. Hum Factors $1981 ; 23: 59-64$.

67 Kline DW. Light, ageing and visual performance. In: Marshall J, ed. The susceptible visual apparatus. London: Macmillan Press, 1991:150-61.

68 Owsley C, McGwin G Jr. Vision impairment and driving. Surv Ophthalmol 1999;43:535-50

69 Owsley C, Stalvey BT, Phillips JM. The efficacy of an educational intervention in promoting self-regulation among high-risk older drivers. Accid Anal Prev 2003;35:393-400.

70 Feeney-Burns L, Ellersieck MR. Age-related changes in the ultrastructure of Bruch's membrane. Am J Ophthalmol 1985;100:686-97.

71 Feeney L, Berman ER. Oxygen toxicity: membrane damage by free radicals. Invest Ophthalmol 1976;15:789-92.

72 Ham WT Jr, Mueller HA, Ruffolo JJ Jr, et al. Basic mechanisms underlying the production of photochemical lesions in the mammalian retina. Curr Eye Res 1984;3:165-74.

73 Boulton M, Rozanowska M, Rozanowski B. Retinal photodamage. J Photochem Photobiol B 2001;64:144-61.

74 Ben-Shabat S, Parish CA, Hashimoto $M$, et al. Fluorescent pigments of the retinal pigment epithelium and age-related macular degeneration. Bioorg Med Chem Lett 2001;11:1533-40.

75 Snodderly DM. Evidence for protection against age-related macular degeneration by carotenoids and antioxidant vitamins. Am J Clin Nutr 1995;62(Suppl): 1448-61.

76 Kennedy CJ, Rakoczy PE, Constable IJ. Lipofuscin of the retinal pigment epithelium: a review. Eye 1995:9(P+ 6):763-71.

77 Reme C, Reinboth J, Clausen M, et al. Light damage revisited: converging evidence, diverging views? Graefes Arch Clin Exp Ophthalmol 1996;234:2-11.

78 Friedman E, Kuwabara T. The retinal pigment epithelium. IV. The damaging effects of radiant energy. Arch Ophthalmol 1968:80:265-79.

79 Mainster MA. Destructive light adaptation. Ann Ophthalmol 1970;2:44-8.

80 White TJ, Mainster MA, Wilson PW, et al. Chorioretinal temperature increases from solar observation. Bull Math Biophys 1971;33:1-17.

81 Gorgels TG, van Beek L, van Norren D. Effect of body temperature on retinal damage by $488 \mathrm{~nm}$ light in rat. Microsc Res Tech 1997;36:89-95.

82 Grimm C, Wenzel A, Hafezi F, et al. Gene expression in the mouse retina: the effect of damaging light. Mol Vis 2000;6:252-60.

83 Grimm C, Wenzel A, Hafezi F, et al. Protection of Rpe65-deficient mice identifies rhodopsin as a mediator of light-induced retinal degeneration. Nat Genet 2000;25:63-6.

84 Wenzel A, Grimm C, Samardzija M, et al. The genetic modifier Rpe65Leu(450): effect on light damage susceptibility in c-Fos-deficient mice. Invest Ophthalmol Vis Sci 2003:44:2798-802.

85 Organisciak DT, Darrow RM, Barsalou L, et al. Light history and age-related changes in retinal light damage. Invest Ophthalmol Vis Sci 1998;39:1107-16.

86 Organisciak DT, Darrow RM, Barsalou L, et al. Circadian-dependent retinal light damage in rats. Invest Ophthalmol Vis Sci 2000:41:3694-701.

87 Vaughan DK, Nemke JL, Fliesler SJ, et al. Evidence for a circadian rhythm of susceptibility to retinal light damage. Photochem Photobiol 2002; 75:547-53.

88 Beatrice J, Wenzel A, Reme CE, et al. Increased light damage susceptibility at night does not correlate with RPE65 levels and rhodopsin regeneration in rats. Exp Eye Res 2003;76:695-700.

89 Tso MO. Retinal photic injury in normal and scorbutic monkeys. Trans Am Ophthalmol Soc 1987:85:498-556.

90 Wiegand RD, Koutz CA, Chen $\mathrm{H}$, et al. Effect of dietary fat and environmental lighting on the phospholipid molecular species of rat photoreceptor membranes. Exp Eye Res 1995;60:291-306.

91 Koutz CA, Wiegand RD, Rapp LM, et al. Effect of dietary fat on the response of the rat retina to chronic and acute light stress. Exp Eye Res 1995:60:307-16.

92 Aonuma H, Koide K, Masuda K, et al. Retinal light damage: protective effect of alpha-tocopherol. Jpn J Ophthalmol 1997;41:160-7.

93 Gorgels TG, van Norren D. Ultraviolet and green light cause different types of damage in rat retina. Invest Ophthalmol Vis Sci 1995;36:851-63.

94 Reme CE, Hafezi F, Marti A, et al. Light damage to the retinal pigment epithelium. In: Marmor MF, Wolfensberger TJ, eds. The retinal pigment epithelium: function and disease. New York: Oxford University Press, 1998.

95 Griess GA, Blankenstein MF. Additivity and repair of actinic retinal lesions. Invest Ophthalmol Vis Sci 1981;20:803-7.

96 van der Hoeve J. Eye lesions produced by light rich in ultraviolet rays: senile cataract, senile degeneration of the macula. Am J Ophthalmol 1920;3:178-94.

97 Ts'o MO, La Piana FG, Appleton B. The human fovea after sungazing. Trans Am Acad Ophthalmol Otolaryngol 1974;78:OP-677.

98 Marshall J. Radiation and the ageing eye. Ophthalmic Physiol Opt 1985;5:241-63

99 Young RW. Solar radiation and age-related macular degeneration. Surv Ophthalmol 1988;32:252-69. 
100 Weale RA. Do years or quanta age the retina? Photochem Photobiol 1989;50:429-38.

101 Marshall J. Ageing changes in human cones. Acta XXIII Concilium Ophthalmologicum (Kyoto) 1978;1:375-8

102 Borges J, Li ZY, Tso MO. Effects of repeated photic exposures on the monkey macula. Arch Ophthalmol 1990;108:727-33.

103 Liu IY, White L, LaCroix AZ. The association of age-related macular degeneration and lens opacities in the aged. Am J Public Health 1989:79:765-9.

104 Taylor HR, Munoz B, West S, et al. Visible light and risk of age-related macular degeneration. Trans Am Ophthalmol Soc 1990;88:163-73, discussion 173-8.

105 Taylor HR, West S, Munoz B, et al. The long-term effects of visible light on the eye. Arch Ophthalmol 1992;110:99-104.

106 Cruickshanks KJ, Klein R, Klein BE. Sunlight and age-related macular degeneration. The Beaver Dam Eye Study. Arch Ophthalmol 1993;111:514-8.

107 Darzins $\mathrm{P}$, Mitchell P, Heller RF. Sun exposure and age-related macular degeneration. An Australian case-control study. Ophthalmology 1997; 104:770-6.

108 Cruickshanks KJ, Klein R, Klein BE, et al. Sunlight and the 5-year incidence of early age-related maculopathy: the Beaver Dam Eye Study. Arch Ophthalmol 2001;119:246-50.

109 Delcourt C, Carriere I, Ponton-Sanchez A, et al. Light exposure and the risk of age-related macular degeneration: the Pathologies Oculaires Liees a l'Age (POLA) study. Arch Ophthalmol 2001;119:1463-8.

110 McCarty CA, Mukesh BN, Fu CL, et al. Risk factors for age-related maculopathy: the Visual Impairment Project. Arch Ophthalmol 2001;119:1455-62.

111 Oliver M. Posterior pole changes after cataract extraction in elderly subjects. Am J Ophthalmol 1966:62:1145-8.

112 Pollack A, Marcovich A, Bukelman A, et al. Age-related macular degeneration after extracapsular cataract extraction with intraocular lens implantation. Ophthalmology 1996;103:1546-54.

113 Van der Schaft TL, Mooy CM, de Bruijn WC, et al. Increased prevalence of disciform macular degeneration after cataract extraction with implantation of an intraocular lens. Br J Ophthalmol 1994;78:441-5.

114 Pollack A, Marcovich A, Bukelman A, et al. Development of exudative agerelated macular degeneration after cataract surgery. Eye 1997; 11(Pt 4):523-30.

115 Armbrecht AM, Findlay C, Kaushal S, et al. Is cataract surgery justified in patients with age related macular degeneration? A visual function and quality of life assessment. Br J Ophthalmol 2000;84:1343-8.

116 Armbrecht AM, Findlay C, Aspinall PA, et al. Cataract surgery in patients with age-related macular degeneration: one-year outcomes. J Cataract Refract Surg 2003;29:686-93.

117 Klein R, Klein BE, Wong TY, et al. The association of cataract and cataract surgery with the long-term incidence of age-related maculopathy: the Beaver Dam eye study. Arch Ophthalmol 2002;120:1551-8.

118 Wong TY. Cataract surgery in patients with cataract and age related macular degeneration: do the benefits outweigh the risks? Br J Ophthalmol 2000;84:1337-8

119 Freeman EE, Munoz B, West SK, et al. Is there an association between cataract surgery and age-related macular degeneration? Data from three population-based studies. Am J Ophthalmol 2003:135:849-56.

120 Sliney DH, Wolbarsht ML. Safety with lasers and other optical sources: a comprehensive handbook. New York: Plenum Press, 1980

121 Kremers JJ, van Norren D. Retinal damage in macaque after white light exposures lasting ten minutes to twelve hours. Invest Ophthalmol Vis $\mathrm{Sci}$ 1989;30:1032-40

122 Van Norren D, Schellekens P. Blue light hazard in rat. Vis Res 1990;30:1517-20.

123 Rapp LM, Smith SC. Morphologic comparisons between rhodopsinmediated and short-wavelength classes of retinal light damage. Invest Ophthalmol Vis Sci 1992;33:3367-77.

124 Williams TP, Howell WL. Action spectrum of retinal light-damage in albino rats. Invest Ophthalmol Vis Sci 1983;24:285-7.

125 Pautler EL, Morita M, Beezley D. Hemoprotein(s) mediate blue light damage in the retinal pigment epithelium. Photochem Photobiol 1990;51:599-605.

126 Saari JC, Garwin GG, Van Hooser JP, et al. Reduction of all-trans-retinal limits regeneration of visual pigment in mice. Vis Res 1998;38:1325-33.

127 Grimm C, Reme CE, Rol PO, et al. Blue Light's effects on rhodopsin: photoreversal of bleaching in living rat eyes. Invest Ophthalmol Vis Sci 2000;41:3984-90.

128 Grimm C, Wenzel A, Williams T, et al. Rhodopsin-mediated blue-light damage to the rat retina: effect of photoreversal of bleaching. Invest Ophthalmol Vis Sci 2001:42:497-505.

129 Parish CA, Hashimoto M, Nakanishi K, et al. Isolation and one-step preparation of $\mathrm{A} 2 \mathrm{E}$ and iso-A2E, fluorophores from human retinal pigment epithelium. Proc Natl Acad Sci USA 1998:95:14609-13.

130 Rozanowska M, Jarvis-Evans J, Korytowski W, et al. Blue light-induced reactivity of retinal age pigment. In vitro generation of oxygen-reactive species. J Biol Chem 1995;270:18825-30.

131 Schutt F, Davies S, Kopitz J, et al. Photodamage to human RPE cells by A2-E, a retinoid component of lipofuscin. Invest Ophthalmol Vis Sci 2000:41:2303-8.

132 Suter M, Reme C, Grimm C, et al. Age-related macular degeneration. The lipofusion component $\mathrm{N}$-retinyl-N-retinylidene ethanolamine detaches proapoptotic proteins from mitochondria and induces apoptosis in mammalian retinal pigment epithelial cells. J Biol Chem 2000;275:39625-30.
133 Sparrow JR, Nakanishi K, Parish CA. The lipofuscin fluorophore A2E mediates blue light-induced damage to retinal pigmented epithelial cells. Invest Ophthalmol Vis Sci 2000;41:1981-9.

134 Sparrow JR, Cai B. Blue light-induced apoptosis of A2E-containing RPE: involvement of caspase-3 and protection by Bcl-2. Invest Ophthalmol Vis Sci 2001;42:1356-62.

135 Rozanowska M, Korytowski W, Rozanowski B, et al. Photoreactivity of aged human RPE melanosomes: a comparison with lipofuscin. Invest Ophthalmol Vis Sci 2002;43:2088-96.

136 Sparrow JR, Zhou J, Cai B. DNA is a target of the photodynamic effects elicited in A2E-laden RPE by blue-light illumination. Invest Ophthalmol Vis Sci 2003;44:2245-51

137 Sparrow JR. Therapy for macular degeneration: insights from acne. Proc Natl Acad Sci USA 2003;100:4353-4.

138 Ben-Shabat S, Parish CA, Vollmer HR, et al. Biosynthetic studies of A2E, a major fluorophore of retinal pigment epithelial lipofuscin. J Biol Chem 2002;277:7183-90.

139 Sparrow JR, Vollmer-Snarr HR, Zhou J, et al. A2E-epoxides damage DNA in retinal pigment epithelial cells. Vitamin $\mathrm{E}$ and other antioxidants inhibit $\mathrm{A} 2 \mathrm{E}$ epoxide formation. J Biol Chem 2003;278:18207-13.

140 Sparrow JR, Parish CA, Hashimoto M, et al. A2E, a lipofuscin fluorophore, in human retinal pigmented epithelial cells in culture. Invest Ophthalmol Vis Sci 1999:40:2988-95.

141 Ham WT Jr, Ruffolo JJ Jr, Mueller HA, et al. The nature of retinal radiation damage: dependence on wavelength, power level and exposure time. Vis Res 1980;20:1105-11.

142 Katz ML, Eldred GE, Robison WG Jr. Lipofuscin autofluorescence: evidence for vitamin A involvement in the retina. Mech Ageing Dev 1987;39:81-90.

143 Katz ML, Redmond TM. Effect of Rpe65 knockout on accumulation of lipofuscin fluorophores in the retinal pigment epithelium. Invest Ophthalmol Vis Sci 2001:42:3023-30.

144 Liu J, Itagaki Y, Ben-Shabat S, et al. The biosynthesis of A2E, a fluorophore of aging retina, involves the formation of the precursor, A2-PE, in the photoreceptor outer segment membrane. J Biol Chem 2000;275:29354-60.

145 Katz ML, Drea CM, Eldred GE, et al. Influence of early photoreceptor degeneration on lipofuscin in the retinal pigment epithelium. Exp Eye Res 1986:43:561-73.

146 Feeney-Burns L, Berman ER, Rothman $\mathrm{H}$. Lipofuscin of human retinal pigment epithelium. Am J Ophthalmol 1980;90:783-91.

147 Weiter JJ, Delori FC, Wing GL, et al. Retinal pigment epithelial lipofuscin and melanin and choroidal melanin in human eyes. Invest Ophthalmol Vis Sci 1986;27:145-52.

148 Feeney-Burns L, Hilderbrand ES, Eldridge S. Aging human RPE: morphometric analysis of macular, equatorial, and peripheral cells. Invest Ophthalmol Vis Sci 1984:25:195-200.

149 Dorey CK, Wu G, Ebenstein D, et al. Cell loss in the aging retina. Relationship to lipofuscin accumulation and macular degeneration. Invest Ophthalmol Vis Sci 1989;30:1691-9.

150 von Ruckmann A, Fitzke FW, Bird AC. Fundus autofluorescence in agerelated macular disease imaged with a laser scanning ophthalmoscope. Invest Ophthalmol Vis Sci 1997;38:478-86.

151 Delori FC, Fleckner MR, Goger DG, et al. Autofluorescence distribution associated with drusen in age-related macular degeneration. Invest Ophthalmol Vis Sci 2000:41:496-504.

152 Lawwill T. Effects of prolonged exposure of rabbit retina to low-intensity light. Invest Ophthalmol 1973;12:45-51.

153 Hoppeler T, Hendrickson P, Dietrich C, et al. Morphology and time-course of defined photochemical lesions in the rabbit retina. Curr Eye Res 1988:7:849-60.

154 Gorgels TG, Van Norren D. Two spectral types of retinal light damage occur in albino as well as in pigmented rat: no essential role for melanin. Exp Eye Res 1998;66:155-62.

155 Mantyjarvi M, Syrjakoski J, Tuppurainen K, et al. Colour vision through intraocular lens. Acta Ophthalmol Scand 1997:75:166-9.

156 Kamel ID, Parker JA. Protection from ultraviolet exposure in aphakic erythropsia. Can J Ophthalmol 1973;8:563-5.

157 Saraux H, Manent JP, Laroche L. Erythropsia in a patient with lens implant. Physiologic and electrophysiologic study. J Fr Ophtalmol 1984;7:557-62.

158 Jordan DR, Valberg JD. Dyschromatopsia following cataract surgery Can J Ophthalmol 1986;21:140-3.

159 Bennett LW. Pseudophakic erythropsia. J Am Optom Assoc 1994;65:273-6.

160 Werner JS, Steele VG, Pfoff DS. Loss of human photoreceptor sensitivity associated with chronic exposure to ultraviolet radiation. Ophthalmology 1989;96:1552-8

161 Miyake K, Ichihashi S, Shibuya Y, et al. Blood-retinal barrier and autofluorescence of the posterior polar retina in long-standing pseudophakia. J Cataract Refract Surg 1999:25:891-7.

162 Peyman GA, Zak R, Sloane H. Ultraviolet-absorbing pseudophakos: an efficacy study. J Am Intraocul Implant Soc 1983;9:161-70.

163 Nilsson SE, Textorius O, Andersson BE, et al. Clear PMMA versus yellow intraocular lens material. An electrophysiologic study on pigmented rabbits regarding "the blue light hazard". Prog Clin Biol Res 1989;314:539-53.

164 Kraff MC, Sanders DR, Jampol LM, et al. Effect of an ultraviolet-filtering intraocular lens on cystoid macular edema. Ophthalmology 1985:92:366-9.

165 Komatsu M, Kanagami S, Shimizu K. Ultraviolet-absorbing intraocular lens versus non-UV-absorbing intraocular lens: comparison of angiographic cystoid macular edema. J Cataract Refract Surg 1989;15:654-7.

166 Schefrin BE, Bieber ML, McLean R, et al. The area of complete scotopic spatial summation enlarges with age. J Opt Soc Am A Opt Image Sci Vis 1998;15:340-8. 
167 Allikmets R. Simple and complex ABCR: genetic predisposition to retinal disease. Am J Hum Genet 2000;67:793-9.

168 Boynton RM. Frederic lves Medal paper. History and current status of a physiologically based system of photometry and colorimetry. J Opt Soc Am A 1996;13:1609-21.
169 Lund DJ, Stuck BE. Study rewrites blue light hazard: the retina's damage threshold to blue laser light may be much higher than previously believed. International Laser Safety Conference, 2003 ( www.optics.org/articles) news/9/4/1/1): Optics.org, 2 April 2003, 2003.

170 Le Grand Y. Light, color and vision. 2nd ed. London: Chapman and Hall, 1968.

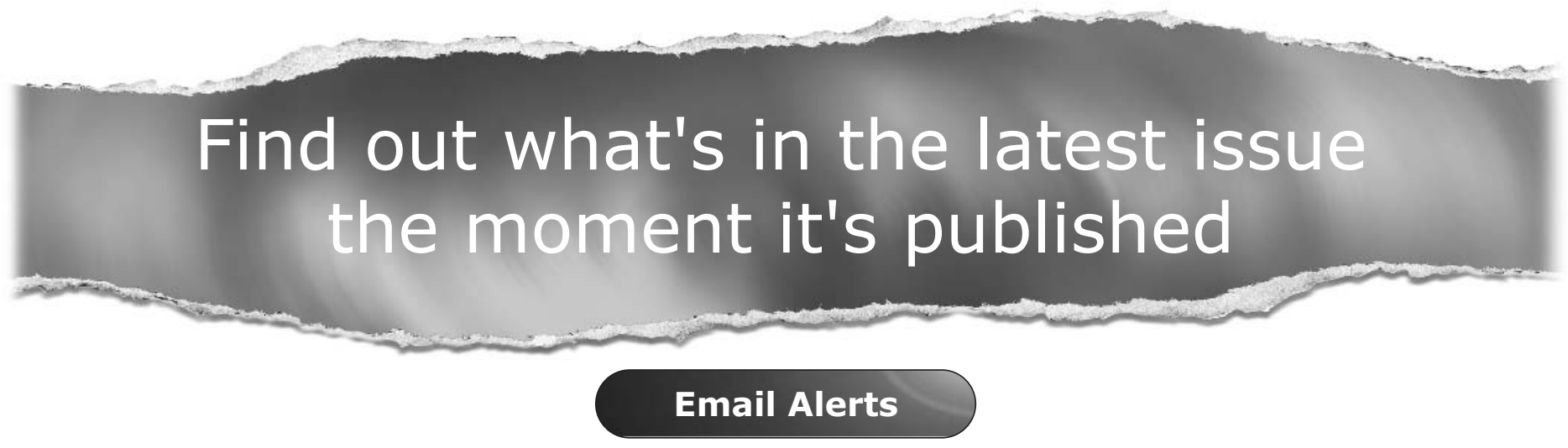

Sign up to receive the table of contents by email every month. You can select from three alerts: Table of Contents (full), TOC Awareness (notice only); British Journal of Ophthalmology related announcements.

www.bjophthalmol.com 